\title{
The effect of residual nitrogen fertilization on the yield components, forage quality, and performance of beef cattle fed on Mombaça grass
}

\section{Efecto residual de la fertilización nitrogenada sobre los componentes de la producción, la calidad de forraje y la performance del ganado de carne en la gramínea mombaça}

Antonio Leandro Chaves Gurgel ${ }^{1 *}$, Gelson dos Santos Difante ${ }^{1}$, Denise Baptaglin Montagner ${ }^{2}$, Alexandre Romeiro de Araujo ${ }^{2}$, Valeria Pacheco Batista Euclides ${ }^{2}$

Originales: Recepción: 16/08/2019 - Aceptación: 07/07/2020

\begin{abstract}
The objective of this study was to evaluate the effect of residual nitrogen $(\mathrm{N})$ on pastures of Mombaça grass and its impact on pasture structure and the nutritive value and performance of beef cattle. The experiment analyzed randomized blocks subdivided into plots, with three replications. The research focused on a number of pastures having received three annual doses of $\mathrm{N}\left(100,200\right.$ and $\left.300 \mathrm{~kg} \mathrm{ha}^{-1}\right)$ from 2015 to 2017, with no N fertilization in 2018. The results indicated that pastures under residual effect of $300 \mathrm{~kg} \mathrm{ha}^{-1}$ of $\mathrm{N}$ were characterized by higher $(\mathrm{P}<0.05)$ rates of forage accumulation than those under the residual effect of $100 \mathrm{~kg} \mathrm{ha}^{-1} \mathrm{~N}$. Furthermore, this study indicated no effect $(\mathrm{P}>0.05)$ on the pasture nutritive value and average daily gain $\left(0.490 \mathrm{~kg} \mathrm{day}^{-1}\right)$. The stocking rate was higher $(\mathrm{P}<0.05)$ in pastures under the residual effect of $300 \mathrm{~kg} \mathrm{ha}^{-1} \mathrm{of} \mathrm{N}$, and lower in those at $100 \mathrm{~kg} \mathrm{ha}^{-1}$ of $\mathrm{N}$, while weight gain per area followed the trend observed in the stocking rate. The results thus suggest that the suspension of $\mathrm{N}$ fertilization for one year after three years of sequential fertilization was responsible for an immediate loss of 50 and $55 \%$ of the productivity of plants and animals, respectively.
\end{abstract}

Keywords

pasture fertilization • forage accumulation • Panicum maximum • stocking rate

1 Universidade Federal de Mato Grosso do Sul. Faculdade de Medicina Veterinária e Zootecnia. Av. Senador Felinto Muller 2443. Vila Ipiranga. C.P. 79070-900. Campo Grande. Mato Grosso Sul. Brasil. * antonioleandro09@gmail.com

2 Empresa Brasileira de Pesquisa Agropecuária. EMBRAPA Gado de Corte. Av. Rádio Maia 830. Vila Popular. C.P. 79106-550. Campo Grande, Mato Grosso do Sul. Brasil. 


\section{RESUMEN}

El objetivo fue evaluar el efecto del nitrógeno residual y su impacto en la estructura y valor nutritivo del forraje y variables productivas del ganado vacuno de carne en pasturas de Mombaça. El diseño experimental fue en bloques al azar, en parcelas subdivididas, con tres repeticiones. Las pasturas recibieron tres dosis anuales de nitrógeno (N) (100, 200 y $\left.300 \mathrm{~kg} \mathrm{ha}^{-1}\right)$ de 2015 a 2017. La fertilización se suspendió en 2018, para estimar el efecto residual del nutriente. Las pasturas que recibieron $300 \mathrm{~kg} \mathrm{ha}^{-1} \mathrm{de} \mathrm{N}$ mostraron un efecto residual en tasa de acumulación de forraje más alto $(\mathrm{P}<0,05)$ que las que recibieron $100 \mathrm{~kg} \mathrm{ha}^{-1} \mathrm{~N}$. No hubo efecto $(P>0,05)$ para valor nutricional de forraje ni ganancia diaria promedio $\left(0,490 \mathrm{~kg} \mathrm{día}^{-1}\right)$. La carga animal fue mayor $(\mathrm{P}<0,05)$ en pasturas bajo el efecto residual de $300 \mathrm{~kg} \mathrm{ha}^{-1}$ de $\mathrm{N}$, y menor en el efecto residual de $100 \mathrm{~kg} \mathrm{ha}^{-1} \mathrm{de} \mathrm{N}$, y el aumento de peso por área siguió la tendencia observada en la carga animal. La suspensión de la fertilización nitrogenada durante un año después de tres años de fertilización secuencial en Mombaça pastoreados por ganado promueve pérdidas inmediatas de 50 y $55 \%$ de la productividad de plantas y animales, respectivamente.

Palabras clave

fertilización de pasturas • acumulación de forraje • Panicum maximum • carga animal

\section{INTRODUCTION}

Beef cattle production in Brazil represents an essential segment of the economy. The high potential for the use of tropical grasses established since the 1990s, is the responsible factor for the increase of productivity indexes in livestock. Despite the large pasture area, many production units do not yet fulfill their full production capacity due to poor management of the soil-plant-animal system. Failures in grazing management (stocking rate adjustments) and pasture maintenance fertilization lead to an unsuccessful activity, which reduces the ability to generate income making it financially unsustainable over the years.

Nitrogen (hereinafter $\mathrm{N}$ ) fertilization along with maintenance fertilization are fundamental to ensure pasture productivity $(22,35)$, and the failure to adopt these technologies is considered one of the primary triggers of degradation. The productivity of a pasture is evaluated based on the individual performance of the animals and the stocking rate used $(13,18)$. The individual performance depends on the genetic potential of the animal (19) and the quantity, quality, and form of forage that it is fed (15). Also, the $\mathrm{N}$ fertilization promotes increases in forage accumulation (5), altering pasture dynamics $(20,28)$ with direct reflexes in animal and per area production (16).

Although forage production can improve with $\mathrm{N}$ fertilization $(6,20)$, increasing secondary productivity (9), the use of $\mathrm{N}$ has been limited by cost, due to the extension of the areas involved and the need for frequent applications. In addition, $\mathrm{N}$ can be easily lost when not associated with the organic fraction of the soil (37). Research evaluating the residual effect of nitrogen has shown promising results for agricultural crops $(29,36)$. Thus, a better understanding of the responses of forage plants and animals to residual fertilization with $\mathrm{N}$ may suggest an alternative way to reduce costs by managing inputs, mechanization and labor, in addition to revealing the impact of not using $\mathrm{N}$ fertilization on productivity (35).

The current study tests the hypothesis that suspending $\mathrm{N}$ fertilization of Mombaça grass for one year after three years of sequential fertilization with the same doses, promotes a residual effect of $\mathrm{N}$ on pasture structure, as well as on the forage nutritive value and the performance of beef cattle. To determine this, the research evaluates the residual effect of $\mathrm{N}$ on Mombaça grass and the impact of this effect on structure and nutritive value of the sward and performance of beef cattle. 


\section{MATERIAL AND METHODS}

\section{Experiment location and edaphoclimatic monitoring}

The experiment was carried out at Embrapa Beef Cattle in Campo Grande, Mato Grosso Sul (figure 1). The experimental area is situated at latitude $20^{\circ} 27^{\prime} \mathrm{S}$ and longitude $54^{\circ} 37^{\prime} \mathrm{W}$ and boasts an average altitude of $530 \mathrm{~m}$ above sea level. The experiment took place over 196 days from $11 / 07 / 2017$ to $05 / 22 / 2018$.
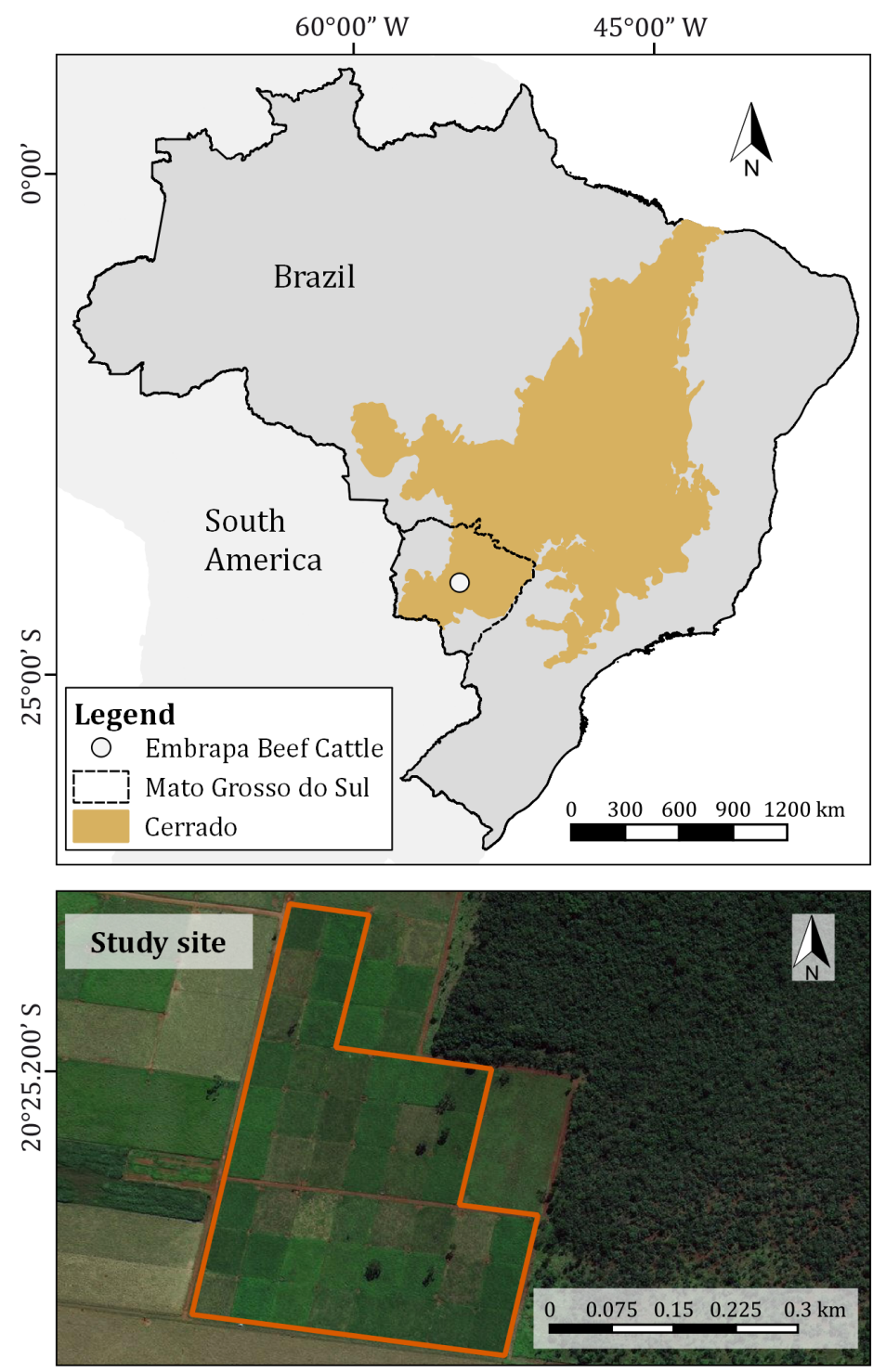

Mombaça pasture

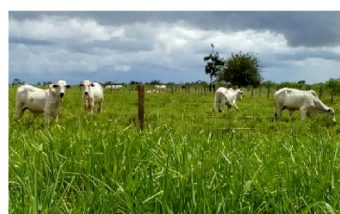

Nellore tester steers

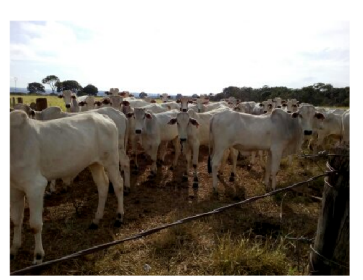

Pre-grazing condition

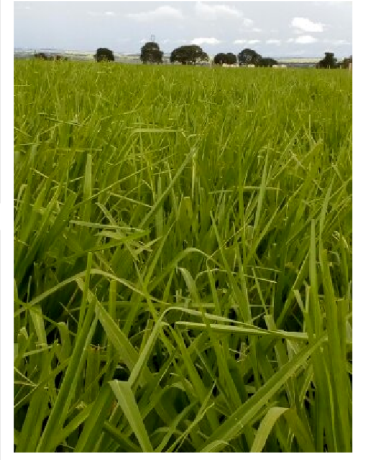

Post-grazing condition

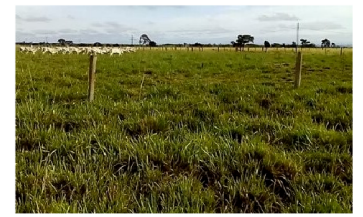

Figure 1. Geographic location of the experimental area and experimental conditions.

Figura 1. Ubicación geográfica del área experimental y condiciones experimentales.

According to the Köppen climate classification, this region is of type AW: a tropical, rainy savannah, with a dry period lasting from May to September, the historical average temperature is $23.4^{\circ} \mathrm{C}$. All precipitation that occurred in the area during the experimental period was documented (figure 2, page 299). Climatic data was extracted from the National Institute of Meteorology (2018) database and gathered by the meteorological station located at Embrapa Beef Cattle. 


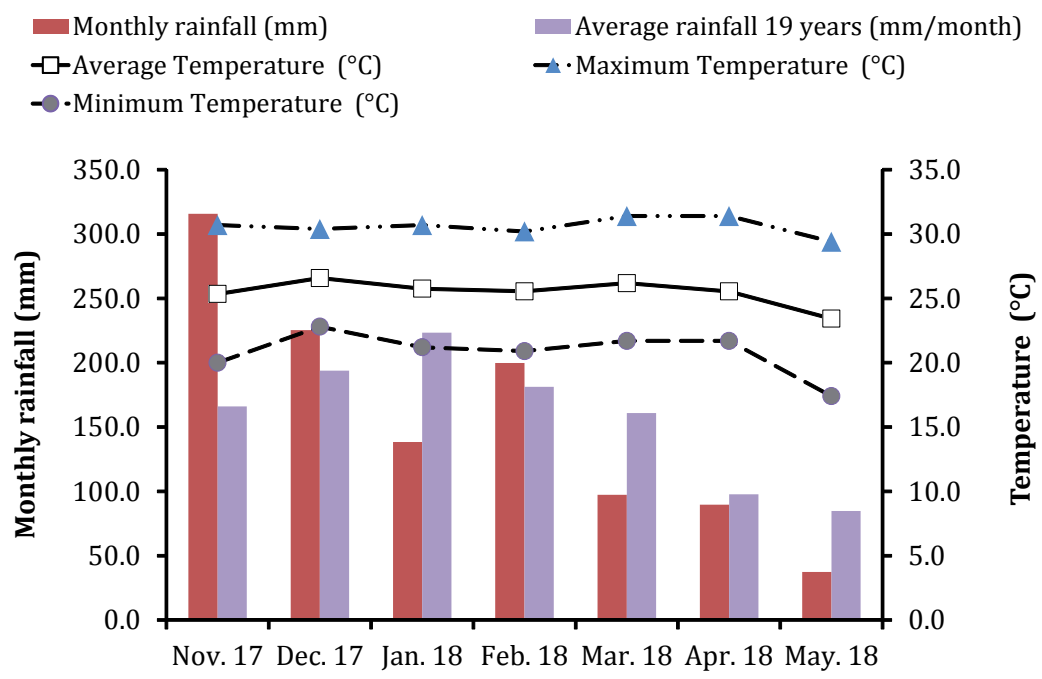

Figure 2. Precipitation and average, minimum, and maximum temperatures during the experimental period and average rainfall for the period year 1 - year 19.

Figura 2. Precipitación y temperaturas promedio, mínima y máxima durante el período experimental y precipitación promedio el período año 1 - año 19.

The average temperature and monthly precipitation were used to calculate the water balance (figure 3). The soil water storage capacity was determined to be $75 \mathrm{~mm}$. The soil of the experimental area is Red Latosol, with clay contents between 30 and 35\%. Before the start of the experiment, the soil was sampled in the 0-10, 0-20 and 20-40 cm layers for chemical analysis (table 1, page 300).

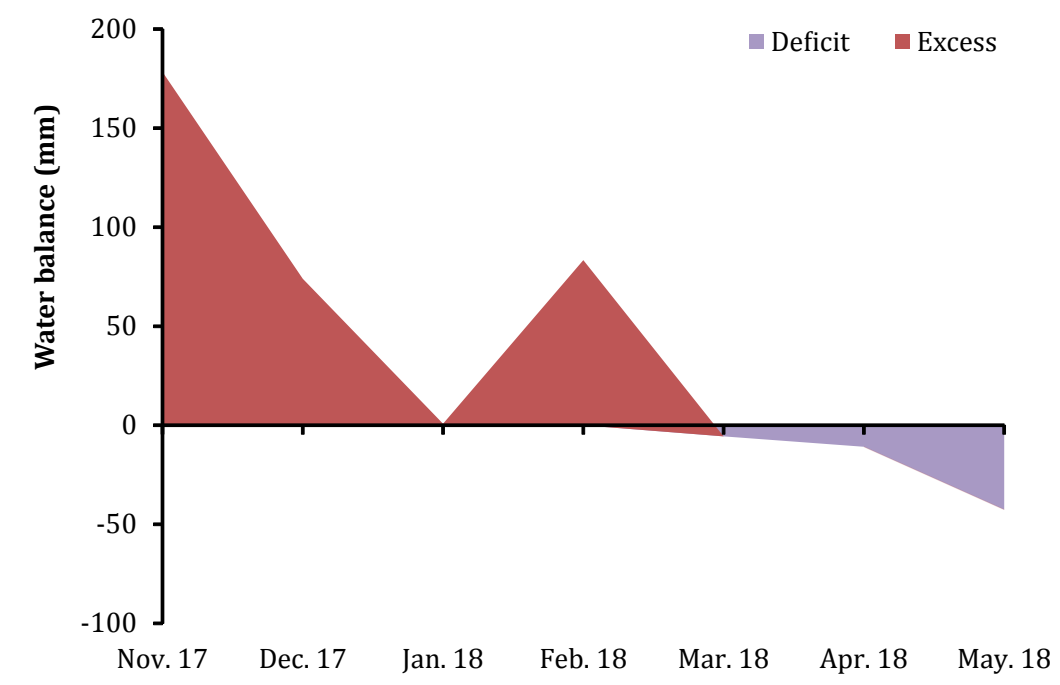

Figure 3. Water deficit and excess in the soil during the experimental period from $11 / 07 / 2017$ to $05 / 11 / 2018$.

Figura 3. Déficit y exceso de agua en el suelo durante el período experimental del 07/11/2017 al 11/05/2018. 
$\mathrm{Ca}^{++}:$Calcium

$\mathrm{Mg}^{++}$: Magnesium;

$\mathrm{K}^{+}$: Potassium;

$\mathrm{Al}^{+3}$ : Aluminum

BS: Base sum; T: Cation exchange capacity (CEC)

at $\mathrm{pH}$ 7.0; t: Effective

CEC; V: saturation by

base; m: saturation by

aluminum; OM: Organic

matter; $\mathrm{P}^{*}$ : Phosphorus

by method - Mehlich -1 .

$\mathrm{Ca}^{++}$: calcio;

$\mathrm{Mg}^{++}$: magnesio;

$\mathrm{K}^{+}$: potasio

$\mathrm{Al}^{+3}$ : aluminio; BS: suma

base; T: capacidad de

intercambio catiónico

(CEC) a pH 7,0; t: CEC

efectiva; V: saturación

por base; m: saturación por aluminio

OM: materia orgánica

P*: Fósforo por método Mehlich -1.

Table 1. Chemical characteristics of the soil in the experimental area, in the depths of the layers of $0-10,0-20$ and $20-40 \mathrm{~cm}$.

Tabla 1. Características químicas del suelo en el área experimental, en las profundidades de las capas de 0-10, 0-20 y 20-40 cm.

\begin{tabular}{|c|c|c|c|c|c|c|c|c|c|c|c|c|c|}
\hline \multirow[t]{2}{*}{ Layer } & pH & $\mathrm{Ca}^{++}$ & $\mathbf{M g}^{++}$ & $\mathbf{K}^{+}$ & $\mathrm{Al}^{+3}$ & $\mathbf{H}+\mathbf{A l}$ & BS & $\mathbf{T}$ & $\mathbf{t}$ & V & $\mathbf{m}$ & $\mathbf{O M}$ & \multirow{2}{*}{$\begin{array}{c}\mathrm{P}^{*} \\
\mathrm{mg} / \mathrm{dm}^{-3}\end{array}$} \\
\hline & $\mathrm{CaCl}_{2}$ & \multicolumn{8}{|c|}{-.--- cmolc/dm ${ }^{-3}$} & \multicolumn{3}{|c|}{$\%$} & \\
\hline $0-10$ & 5.7 & 2.5 & 1.3 & 0.4 & 0.2 & 3.5 & 4.1 & 7.6 & 4.1 & 54.2 & 0.4 & 4.2 & 8.4 \\
\hline $0-20$ & 5.6 & 2.4 & 1.2 & 0.3 & 0.1 & 3.1 & 3.9 & 7.0 & 3.9 & 56.0 & 0.3 & 3.9 & 4.9 \\
\hline $20-40$ & 5.5 & 1.3 & 0.9 & 0.2 & 0.2 & 3.0 & 2.4 & 5.4 & 2.4 & 44.9 & 0.8 & 2.9 & 2.9 \\
\hline
\end{tabular}

\section{Experiment area and management}

The Mombaça grass (Panicum maximum cv. Mombaça) studied was initially planted in January 2008 (Blocks I and II) and November 2010 (Block III) and has since been used for the intermittent grazing of beef cattle. The experimental area of 13.5 ha was divided into three blocks, with each block further subdivided into three modules of 1.5 ha, each module into six paddocks of 0.25 ha each.

Over three consecutive years 2014/2015, 2015/2016, and 2016/2017, the pastures received three annual doses of $\mathrm{N}$ in the form of urea $\left(100,200\right.$, and $\left.300 \mathrm{~kg} \mathrm{ha}^{-1} \mathrm{of} \mathrm{N}\right)$ and cover fertilization (80 kg ha-1 of P2O5 and $80 \mathrm{~kg}$ of K20) (2, 3). Starting in the rainy season of 2017, there was no maintenance or $\mathrm{N}$ fertilization.

Intermittent grazing with a variable stocking rate was used, involving five days of occupation and 25 days of rest in the first five grazing cycles (summer) and seven days of occupation and 35 days of rest in the sixth grazing cycle (fall). Fifty-four Nellore male, uncastrated bovine animals initially weighing $205 \pm 26.0 \mathrm{~kg}$ (the data is displayed average \pm standard error) were used and remained in the paddocks during the entire experimental period.

A group of six steers serving as test subjects were also present in each paddock during the experimental period. Twenty-six steers were kept in a reserve pasture (5 ha Massai grass) and used as necessary to maintain a post-grazing height of $40-50 \mathrm{~cm}$, as suggested by Euclides et al. (2015). The animals all had access to water and mineral salt ad libitum.

\section{Pasture assessments}

Pasture evaluations were always performed in the same previously chosen paddock of each module and both the pre- and post-grazing conditions were assessed during each cycle. The sward height was measured with a centimeter ruler at 40 different points distributed along five imaginary straight lines across each paddock. The sward height at each point was determined as the average height of the curvature of the leaves around the ruler. The average of each paddock was calculated based on these 40 points.

The forage mass (FM) was estimated by cutting the forage contained in nine rectangular areas of $1 \mathrm{~m}^{2}$ distributed randomly across the paddock. The samples were conditioned in paper bags, weighed, and dried in a forced air ventilation oven at $55^{\circ} \mathrm{C}$ until the weight stabilized, at which point they were again weighed to estimate the forage dry mass.

To evaluate the morphological components, three subsamples were taken and separated into leaf (leaf blade), stem (pseudostem+sheath), and dead material (18). After a manual separation, the components were dried using the same protocol used to evaluate the FM. The leaf to stem ratio was estimated as the product of the mass of leaves and the mass of stems. The net forage accumulation rate (FAR) was calculated by the difference between the FM in the present pre-grazing and after the previous grazing period, considering only the green (leaf and stem) portion, divided by the number of days between the samplings.

The leaf and stem samples obtained in the pre-grazing state were ground using a $1 \mathrm{~mm}$ knife mill and later analyzed for the in vitro digestibility of organic matter and crude protein, neutral detergent fiber, and acid lignin detergent, using the Near Infrared Reflectance Spectrophotometry (NIRS) system and the methodology proposed by Merten et al. (1985). 


\section{Animal evaluations}

All steers were weighed every 56 days. The stocking rate was calculated by multiplying the mean weight of the test subject and control steers by the number of days they remained in the experimental module (31).

The average daily gain was calculated by subtracting the weight of the steers at the end of the experimental period from that at the beginning and dividing the result by the number of days (196). The body weight gain per area (kg/ha) was obtained by multiplying the average daily gain of the subjects by the number of animals kept in each experimental plot.

\section{Experimental design and statistical analysis}

The current study employs a randomized block design with subdivided plots. The data gathered was submitted to an analysis of variance, for the variables related to pasture (forage accumulation, structural characteristics, and nutritive value), the residual effect of the $\mathrm{N}$ doses was allocated in the plot and the grazing cycles in the subplot. The following model was used: Yijk $=\mu+\mathrm{Di}+\mathrm{Bj}+\alpha \mathrm{ij}+\mathrm{Ck}+\left(\mathrm{D}^{*} \mathrm{C}\right) \mathrm{ik}+\beta \mathrm{ijk}$; Yijk = value observed at dose $\mathrm{i}$, block j, cycle $\mathrm{k} ; \mu$ = general average effect; $\mathrm{Bj}=$ effect of block J; Di = dose effect i, i = 100, 200 and 300; $\alpha \mathrm{ij}=$ effect of the random error attributed to the plot; $\mathrm{Ck}=$ effect of cycle $\mathrm{k}, \mathrm{k}=1,2,3, \ldots ;$ (DC) $\mathrm{ik}=$ effect of interaction between dose and cycle; $\beta \mathrm{ijk}=$ random error assigned to the subplot.

For the variables related to the animals (average daily weight, body weight gain per area, and stocking rate) the data was submitted to analysis of variance taking into account the randomized block design. The following model was used: Yij $=\mu+\mathrm{Di}+\mathrm{Bj}+\alpha \mathrm{ij}$, where: YijK = value observed at dose $\mathrm{i}$, repeat $\mathrm{j} ; \mu=$ general average effect; Di = height effect $\mathrm{i}$, $\mathrm{i}=100,200$ and $300 ; \mathrm{Bj}=$ effect of block j; $\alpha \mathrm{ij}=$ effect of random error attributed to repetition $\mathrm{j}$.

When determined to be significant by the F test, the effects of the sources of variation and their interactions were analyzed using the Tukey test, at 5\% significance.

\section{RESULTS AND DISCUSSION}

The interaction between the residual $\mathrm{N}$ effect and the grazing cycles was determined not to be significant $(\mathrm{P}>0.05)$ for the structural variables of the sward, in the pre and post-grazing states. The results revealed no effect of residual $\mathrm{N}$ fertilization on canopy height and dead material mass (DMM) in pre-grazing conditions (table 2, page 302). The forage canopy did not reach $90 \mathrm{~cm}$ of height in the pre-grazing at any residual level of $\mathrm{N}$. This height is significant, because it is the height required for Mombaça grass to intercept $95 \%$ of the light, causing competition for incident light at the base of the plant and triggering an increase in the accumulation of stem and losses by senescence $(10,17,18)$. Although the recommended management of the grazing (fixed days of occupation and rest) was not properly followed, it is possible to infer that there was no elongation of the stem nor any accumulation of dead material in the forage canopy, since the heights remained close at $80 \mathrm{~cm}(90 \%$ of the light intercept, hereinafter LI).

Adhering to this height therefore seems to be a possible method for successfully managing Mombaça grass (1).

Furthermore, the swards with a residual effect of $300 \mathrm{~kg} \mathrm{ha}^{-1}$ of $\mathrm{N}$ were characterized by a higher forage accumulation, FM, leaf blade mass (LBM), and stem mass (SM) than those with a residual effect of $100 \mathrm{~kg} \mathrm{ha}^{-1}$ of $\mathrm{N}$. The averages for these variables in pastures under the residual effect of $200 \mathrm{~kg} \mathrm{ha}^{-1}$ of $\mathrm{N}$ were similar to the those under the effect of the other two levels of residual $\mathrm{N}$ (table 2). As pastures were managed with fixed days of occupation and rest, the results of FM, LBM, and SM reflected forage accumulation and soil fertility history according to the previous management, pointing out the residual effect of $\mathrm{N}$ on the structural characteristics of the pasture. $\mathrm{N}$ accelerates plant metabolism and increases morphogenic processes (4).

The use of higher $\mathrm{N}$ rates therefore appears to be responsible for an increase in leaf appearance and leaf elongation rates $(4,30)$. These morphogenic variables directly affect the structural variables of the pasture $(12,14,20)$ and increase forage accumulation. 
Averages followed by distinct letters in the line differ $(\mathrm{P}<0.05)$ by the Tukey test.

Los promedios seguidos de letras distintas en la línea difieren $(\mathrm{P}<0,05)$ por la prueba de Tukey.
Table 2. Structural variables (average \pm standard error) of the canopy in the pre-grazing of the Mombaça grass under residual nitrogen effect.

Tabla 2. Variables estructurales (media \pm error estándar) pre-pastoreo en la canopia de la gramínea Mombaça bajo efecto residual de nitrógeno.

\begin{tabular}{|c|c|c|c|c|}
\hline \multirow{2}{*}{ Variables } & \multicolumn{3}{|c|}{ Doses of $N\left(\mathrm{~kg} \mathrm{ha}^{-1}\right.$ de $\left.\mathrm{N}\right)$} & \multirow{2}{*}{ P Value } \\
\hline & 100 & 200 & 300 & \\
\hline Canopy height (cm) & $67.1 \pm 2.7$ & $75.2 \pm 2.9$ & $75.8 \pm 2.5$ & 0.326 \\
\hline Forage accumulation rate $\left(\mathrm{kg} \mathrm{ha}^{-1} \mathrm{DM}\right.$ day $\left.^{-1}\right)$ & $26.7^{\mathrm{b}} \pm 4.7$ & $36.3^{\mathrm{ab}} \pm 6.5$ & $43.4^{\mathrm{a}} \pm 6.7$ & 0.020 \\
\hline Forage mass (kg ha-1 DM) & $3371.8^{\mathrm{b}} \pm 86.8$ & $3637.6^{\mathrm{ab}} \pm 92.4$ & $3853.9^{\mathrm{a}} \pm 128.2$ & 0.018 \\
\hline Leaf blade mass (kg ha-1 DM) & $1790.2^{\mathrm{b}} \pm 77.6$ & $1968.8^{\mathrm{ab}} \pm 111.2$ & $2181.7^{\mathrm{a}} \pm 128.4$ & 0.019 \\
\hline Stem mass (kg ha-1 DM) & $578.6^{\mathrm{b}} \pm 26.1$ & $761.5^{\mathrm{ab}} \pm 27.6$ & $856.5^{\mathrm{a}} \pm 43.6$ & 0.040 \\
\hline Dead material mass (kg ha-1 DM) & $989.9 \pm 77.2$ & $905.3 \pm 121.8$ & $815.3 \pm 96.3$ & 0.188 \\
\hline Leaf blade:stem rate & $3.3 \pm 0.2$ & $2.7 \pm 0.2$ & $2.7 \pm 0.1$ & 0.204 \\
\hline
\end{tabular}

Forage accumulation rates were $58.1 \%, 54.3 \%$, and $47.2 \%$ lower for the residual doses of 100,200 and $300 \mathrm{~kg} \mathrm{ha}^{-1}$ of $\mathrm{N}$, respectively than the values observed by Barbosa (2018) in 2017, when the pastures received the doses of N. The lower FAR can be explained by the direct effect of $\mathrm{N}$ fertilization on the forage plant, since the nutrient is responsible for significant increases in forage production $(5,9)$. Pastures under the residual dose of $100 \mathrm{~kg} \mathrm{ha}^{-1}$ of $\mathrm{N}$, presented a pre-grazing FM close to the $3000 \mathrm{~kg} \mathrm{ha}^{-1}$ of DMM observed in a study by Brâncio et al. (2003a).

This study examines Mombaça grass in pastures fertilized with $50 \mathrm{~kg} \mathrm{ha}^{-1}$ of $\mathrm{N}$ having undergone grazing management habits, temperatures and average precipitation similar to those adopted in the current experiment and in the same place (latitude $20^{\circ} 27^{\prime} \mathrm{S}$ and longitude $54^{\circ} 37^{\prime} \mathrm{W}$ ). Therefore, it seems that the residual effect of $100 \mathrm{~kg} \mathrm{ha}^{-1}$ of $\mathrm{N}$ on forage production is equivalent to the direct effect of $50 \mathrm{~kg} \mathrm{ha}^{-1} \mathrm{of} \mathrm{N}$.

The pastures with a residual effect of 200 and $300 \mathrm{~kg} \mathrm{ha}^{-1}$ of $\mathrm{N}$ presented higher masses of leaf and stem, whereas those at $100 \mathrm{~kg} \mathrm{ha}^{-1}$ of $\mathrm{N}$ behaved in opposite ways (table 2). This explains the absence of an effect on the leaf blade to stem ratio, since this ratio is the product of LBM and stem mass.

The SM was similar across the evaluation months (table 3, page 303). Montagner et al. (2012) report a stem elongation rate during the rainy season of 0.04 and $0.003 \mathrm{~cm} /$ day in the summers of the first and second year of evaluation.

Luna et al. (2014) indicate an elongation rate of $0.04 \mathrm{~cm} /$ day. These results suggest that the rest period used was adequate to control the sward structure because the low elongation rates and adequate periods of grazing and rest did not increase significantly for stem mass.

The FAR fluctuated during the evaluation months (table 3, page 303). The highest FAR was observed in February, without statistical difference for the months of January and March, although with variation in the values.

The results of December and April were similar to those of January and March, with all presenting higher FAR than observed in May. The values for height of the pasture were higher in December, January, February and March. On the other hand, FM presented its lowest value in March, with no statistical difference for the months of December, April and May, due to the low accumulation of forage caused by a decrease in temperature and a low rate of precipitation. In December, January and February, the water balance was positive (figure 2 and figure 3, page 299). In fact, the rate offorageaccumulation fluctuates throughout the year as a consequence of climatic variations (figure 2 and figure 3, page 299).

The largest LBM were observed in December and January, while the lowest were in May, a time with increased precipitation and reduced temperature (figure 2, page 299). The value of DMM was highest in May, accounting for about 50\% of the total FM during this period. 
Table 3. Canopy height, forage mass and morphological composition (average \pm standard error) in pre-grazing of Mombaça grass under residual nitrogen effect during grazing cycles.

Tabla 3. Altura de la canopia, biomasa total de forraje y por componente (media \pm error estándar) en el pre-pastoreo de la gramínea Mombaça bajo efecto de nitrógeno residual durante los ciclos de pastoreo.

\begin{tabular}{|c|c|c|c|c|c|c|c|}
\hline \multirow{2}{*}{ Variables } & \multicolumn{6}{|c|}{ Months } & \multirow{2}{*}{ P Value } \\
\hline & Dec/17 & Jan/18 & Feb/18 & Mar/18 & Apr/18 & May/18 & \\
\hline Canopy height (cm) & $75.2^{\mathrm{ab}} \pm 2.2$ & $82.6^{\mathrm{a}} \pm 2.7$ & $83.2^{\mathrm{a}} \pm 3.3$ & $79.6^{\mathrm{ab}} \pm 2.3$ & $61.1^{b} \pm 2.6$ & $54.3^{\mathrm{b}} \pm 1.8$ & 0.005 \\
\hline FAR $\left(\mathrm{kg} \mathrm{ha}^{-1}\right.$ day $\left.^{-1}\right)$ & $25.2^{\mathrm{b}} \pm 2.9$ & $44.8^{\mathrm{ab}} \pm 4.5$ & $62.2^{\mathrm{a}} \pm 4.5$ & $40.3^{\mathrm{ab}} \pm 6.4$ & $20.4^{\mathrm{b}} \pm 1.9$ & $0.5^{\mathrm{c}} \pm 0.1$ & 0.001 \\
\hline FM (Kg ha $\left.{ }^{-1} \mathrm{DM}\right)$ & $3697.8^{\mathrm{ab}} \pm 142.2$ & $4045.2^{\mathrm{a}} \pm 68.9$ & $4068.2^{\mathrm{a}} \pm 87.6$ & $3019.4^{\mathrm{b}} \pm 111.6$ & $3167.8^{\mathrm{ab}} \pm 124.9$ & $3728,0^{\mathrm{ab}} \pm 71.6$ & 0.001 \\
\hline LBM (Kg ha-1 DM) & $2635.5^{\mathrm{a}} \pm 101.8$ & $2295.4^{\mathrm{ab}} \pm 65.9$ & $2170.1^{b} \pm 76.4$ & $1924.4^{\mathrm{bc}} \pm 82.2$ & $1785.48^{\mathrm{c}} \pm 104.8$ & $1070,5^{\mathrm{d}} \pm 74.9$ & 0.001 \\
\hline SM $\left(\mathrm{Kg} \mathrm{ha}^{-1} \mathrm{DM}\right)$ & $668.7 \pm 54.2$ & $761.6 \pm 33.8$ & $855.9 \pm 36.8$ & $628.3 \pm 44.5$ & $678.7 \pm 70.0$ & $800,0 \pm 62.5$ & 0.052 \\
\hline DMM (Kg ha-1 DM) & $392.9^{c} \pm 55.0$ & $988.2^{\mathrm{b}} \pm 55.1$ & $1011.9^{b} \pm 41.3$ & $466.7^{\mathrm{c}} \pm 33.4$ & $703.6^{\mathrm{bc}} \pm 67.9$ & $1857,5^{\mathrm{a}} \pm 98.0$ & 0.001 \\
\hline Leaf blade:stem rate & $4.3^{\mathrm{a}} \pm 0.3$ & $3.2^{\mathrm{b}} \pm 0.1$ & $2.6^{\mathrm{b}} \pm 0.1$ & $3.1^{\mathrm{b}} \pm 0.2$ & $2.7^{\mathrm{b}} \pm 0.2$ & $1,4^{\mathrm{c}} \pm 0.1$ & 0.001 \\
\hline
\end{tabular}

Averages followed by distinct letters in the line differ $(\mathrm{P}<0.05)$ by the Tukey test. FAR: forage accumulation rate; FM: forage mass; LBM: leaf blade mass; SM: stem mass; DMM: dead material mass.

Los promedios seguidos de letras distintas en la línea difieren $(\mathrm{P}<0,05)$ por la prueba de Tukey. FAR: tasa de acumulación de forraje; FM: masa de forraje; LBM: masa de lámina hoja; SM: masa de tallo; DMM: masa de material muerto.

This can be explained in part by the flowering of the cultivar, which occurs in mid-April in Campo Grande (20²50’ S). After the emergence of the inflorescence, no more leaves appear, and there is an increase in the accumulation of dead material (17). This could potentially restrict the consumption of forage (15). However, the dead material, in this condition, was concentrated at the base of the plant (17), forage stratum not exploited by the animals due to the post-grazing height adopted.

In the post-grazing condition, there was no effect $(\mathrm{P}>0.05)$ of residual $\mathrm{N}$ doses on the canopy height $(49.4 \pm 2.3 \mathrm{~cm}), \mathrm{FM}\left(2822.8 \pm 109.3 \mathrm{~kg} \mathrm{ha}^{-1} \mathrm{DM}\right), \mathrm{LBM}\left(891.9 \pm 41.4 \mathrm{Kg} \mathrm{ha}^{-1} \mathrm{DM}\right)$, SM $\left(744.5 \pm 55.1 \mathrm{~kg} \mathrm{ha}^{-1} \mathrm{DM}\right), \mathrm{DMM}\left(1186.7 \pm 82.0 \mathrm{~kg} \mathrm{ha}^{-1} \mathrm{DM}\right)$, and leaf blade to stem ratio $(1.3 \pm 0.2)$. These results are explained by the fact that the stocking rate was adjusted to lower the pastures to $40-50 \mathrm{~cm}$ during the period of occupation, as recommended by Euclides et al. (2015 and 2017). Even using fixed days of occupancy and rest, the adjustment of the stocking rate was performed weekly based on the control of the target height of the residue. This adjustment was essential to controlling the grazing and maintaining the structural conditions of the canopy. Briske et al. (2008) suggest that the adjustment of the stocking rate is the most important tool in managing pastures under intermittent stocking.

The post-grazing height varied over the evaluation months, reaching its highest value in January and February, (table 4, page 304). In turn, January did not differ from the rest of the months. The average height of the plants in the pastures' post-grazing state was above the established target $(40-50 \mathrm{~cm})$. This higher height is likely due to the higher accumulations of forage observed during these months (table 3) and indicated that an increase in the number of animals is not sufficient to lowering the pasture to its target height.

The post-grazing FM was highest in February with a similar value to that observed in May, and this was similar to January and December. The higher rainfall (figure 2, page 299) and daily FAR (table 3) in February explain this result. Even though the low FAR was observed in the month of May, the FM results were similar to the months where they had higher TAF. The flowering of Mombaça grass occurs during this period and, because reproductive tillers are larger than vegetative ones, this modifies the structure sward $(30,32,33)$. Since reproductive tillers are rejected by animals, this also increases the DMM. 
Table 4. Canopy height, forage mass and morphological composition (average \pm standard error) in post-grazing of Mombaça grass under residual nitrogen effect during grazing cycles.

Tabla 4. Altura de la canopia, biomasa total de forraje y por componente (media \pm error estándar) en post-pastoreo de la gramínea Mombaça bajo efecto de nitrógeno residual durante los ciclos de pastoreo.

\begin{tabular}{|c|c|c|c|c|c|c|c|}
\hline \multirow{2}{*}{ Variables } & \multicolumn{6}{|c|}{ Months } & \multirow{2}{*}{ P Value } \\
\hline & Dec/17 & Jan/18 & Feb/18 & Mar/18 & Apr $/ 18$ & May/18 & \\
\hline $\begin{array}{l}\text { Canopy height } \\
\text { (cm) }\end{array}$ & $46.0^{\mathrm{b}} \pm 1.6$ & $52.8^{\mathrm{ab}} \pm 1.2$ & $58.8^{a} \pm 0.7$ & $45.7^{\mathrm{b}} \pm 1.0$ & $47.2^{\mathrm{b}} \pm 1.4$ & $45.7^{\mathrm{b}} \pm 0.8$ & 0.009 \\
\hline FM $\left(\mathrm{kg} \mathrm{ha}^{-1} \mathrm{DM}\right)$ & $2905.1^{\mathrm{b}} \pm 75.8$ & $3004.6^{\mathrm{b}} \pm 83.5$ & $3341.3^{\mathrm{a}} \pm 73.9$ & $2159.4^{c} \pm 49.5$ & $2356.2^{\mathrm{c}} \pm 84.1$ & $3166.9^{\mathrm{ab}} \pm 57.3$ & 0.001 \\
\hline LBM (Kg ha-1 DM) & $1073.4^{\mathrm{a}} \pm 77.7$ & $1213.9^{\mathrm{a}} \pm 28.7$ & $1065.0^{\mathrm{a}} \pm 32.9$ & $661.8^{\mathrm{bc}} \pm 36.2$ & $798.1^{\mathrm{b}} \pm 72.7$ & $539.1^{\mathrm{c}} \pm 46.1$ & 0.001 \\
\hline $\mathrm{SM}\left(\mathrm{Kg} \mathrm{ha}^{-1} \mathrm{DM}\right)$ & $684.3^{\mathrm{b}} \pm 79.6$ & $870.8^{\mathrm{a}} \pm 39.7$ & $832.6^{a} \pm 37.5$ & $683.3^{\mathrm{b}} \pm 39.8$ & $708.1^{\mathrm{b}} \pm 43.4$ & $688.1^{b} \pm 35.1$ & 0.001 \\
\hline DMM (Kg ha $\left.{ }^{-1} \mathrm{DM}\right)$ & $960.9^{\mathrm{cd}} \pm 71.5$ & $1106.4^{c} \pm 41.2$ & $1443.7^{b} \pm 48.2$ & $814.3^{\mathrm{d}} \pm 37.4$ & $855.0^{\text {cd }} \pm 81.8$ & $1939.6^{\mathrm{a}} \pm 75.1$ & 0.001 \\
\hline
\end{tabular}

Averages followed by distinct letters in the line differ $(\mathrm{P}<0.05)$ by the Tukey test. FM: forage mass; LBM: leaf blade mass; SM: stem mass; DMM: dead material mass.

Los promedios seguidos de letras distintas en la línea difieren $(\mathrm{P}<0,05)$ por la prueba de Tukey. FM: masa de forraje; LBM: masa de lámina de hoja; SM: masa de tallo; DMM: masa de material muerto.

The LBM in the post-grazing state decreased over the cycles due to a decrease in the accumulation rate. According to Lopes et al. (2011), the amount of leaves remaining indicates the level of grazing pressure exerted by the animal, with a greater mass of foliar leaf in the post-grazing resulting in better regrowth conditions for the plants. Therefore, it impacts subsequent cycles.

The post-grazing SM was highest in January and February due to the higher entry heights recorded in this period, reflecting the higher forage accumulation (table 3, page 303). The post-grazing DMM was highest in May because of higher values for DMM in the pre-grazing state during this period; the animals reject this component, promoting higher accumulation. The increase in dead material and consequent reduction in leaf mass suggest a loss of efficiency in forage production in periods of lower precipitation and temperature (figure 2, page 299).

There was no interaction between the effect of residual $\mathrm{N}$ and grazing cycles $(\mathrm{P}>0.05)$ for the nutritive values of leaves and stems. There was no difference $(\mathrm{P}>0.05)$ in the residual $\mathrm{N}$ doses for crude protein $(9.3 \pm 0.2 \%)$, neutral detergent fiber $(75.0 \pm 0.4 \%)$, lignin $(2.9 \pm 0.1 \%)$, and in vitro digestibility of organic matter $(55.3 \pm 0.1 \%)$ of the leaf. There was also no effect $(\mathrm{P}>0.05)$ of residual $\mathrm{N}$ doses for crude protein ( $4.5 \pm 0.2 \%)$, neutral detergent fiber $(77.2 \pm 02 \%)$, lignin $(4.2 \pm 0.1 \%)$ and in vitro digestibility of organic matter $(51.1 \pm 0.4 \%)$ of the stem.

These results are probably connected to the short rest period adopted, since the pasture heights observed in pre-grazing conditions were similar (table 2, page 302) and well below $90 \mathrm{~cm}$, a height at which Carnevalli et al. (2006) indicate that the canopy intercepts 95\% LI. In this context, Sbrissia et al. (2013) demonstrate that pastures of Quicuio grass with up to $95 \%$ LI present similar nutritive values to those observed in the current study. Alvarenga et al. (2020) also present similar nutritive values for Mombaça grass pastures managed with 90 and $95 \%$ of the LI. A significant number of studies examine the influence of plant nutrition on the pastures' nutritive value (5). The current study, however, reveals that the suspension of $\mathrm{N}$ fertilization for one year is enough to neutralize the effect of soil fertility on the nutritive value of Mombaça grass.

The nutritive value of the leaf varied over the months of evaluation. In December, January, and February, the highest levels of crude protein and the lowest levels of neutral detergent fiber and acid detergent lignin were observed, altering the in vitro organic matter digestibility (table 5, page 305), due to the reduction in cellular content with the increase of the fibrous portion. The higher forage accumulation in this period (table 3, page 303) caused by a higher rainfall (figure 2, page 299) explains this response. Machado et al. (2008) 
highlight that the availability of water in the soil is a determining factor in the chemical composition of the forage plant. Its presence favors a more intense morphogenesis process, which in turn produces new tissues with a higher nutritive value: such plants, consequently, have a better effect on the animals.

The lower rainfall and consequent soil water deficit and the low temperatures (figure 2, page 299) starting in March are responsible for the lower values of crude protein and higher values of the less degradable parts of the fiber in March, April, and May. This period is therefore critical in animal nutrition.

Table 5. Chemical composition (average \pm standard error) of the Mombaça grass under residual nitrogen effect during grazing cycles.

Tabla 5. Composición química (media \pm error estándar) de la gramínea Mombaça bajo efecto de nitrógeno residual durante los ciclos de pastoreo.

\begin{tabular}{|c|c|c|c|c|c|c|c|}
\hline \multirow{2}{*}{ Variables } & \multicolumn{6}{|c|}{ Months } & \multirow{2}{*}{$\begin{array}{c}\mathbf{P} \\
\text { Value }\end{array}$} \\
\hline & Dec/17 & Jan/18 & Feb/18 & Mar/18 & Apr $/ 18$ & May/18 & \\
\hline \multicolumn{8}{|c|}{ 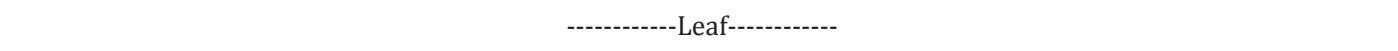 } \\
\hline Crude protein & $9.8^{\mathrm{ab}} \pm 0.2$ & $11.4^{\mathrm{a}} \pm 0.3$ & $9.3^{\mathrm{ab}} \pm 0.1$ & $8.6^{\mathrm{b}} \pm 0.1$ & $8.8^{b} \pm 0.1$ & $8.0^{c} \pm 0.3$ & 0.001 \\
\hline Neutral detergent fiber & $73.9^{\mathrm{cb}} \pm 0.3$ & $73.3^{c} \pm 0.5$ & $75.0^{\mathrm{b}} \pm 0.2$ & $73.1^{\mathrm{c}} \pm 0.4$ & $76.8^{\mathrm{a}} \pm 0.2$ & $78.1^{\mathrm{a}} \pm 0.2$ & 0.001 \\
\hline Lignin & $2.6^{c} \pm 0.1$ & $2.6^{c} \pm 0.1$ & $2,9^{\mathrm{b}} \pm 0.1$ & $3.1^{\mathrm{ab}} \pm 0.1$ & $3.2^{\mathrm{a}} \pm 0.1$ & $3.2^{\mathrm{a}} \pm 0.1$ & 0.001 \\
\hline IVOMD & $61.0^{\mathrm{a}} \pm 0.4$ & $58.3^{\mathrm{b}} \pm 0.7$ & $55.3^{\mathrm{c}} \pm 0.4$ & $56.1^{\mathrm{c}} \pm 0.1$ & $51.2^{\mathrm{d}} \pm 0.1$ & $50.0^{\mathrm{d}} \pm 0.7$ & 0.001 \\
\hline \multicolumn{8}{|c|}{ 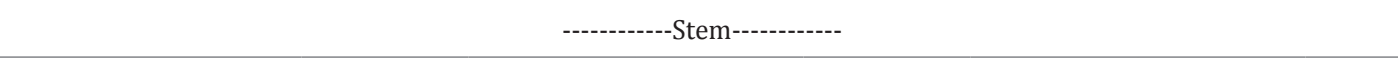 } \\
\hline Crude protein & $5.2^{\mathrm{a}} \pm 0.2$ & $5.0^{\mathrm{a}} \pm 0.2$ & $4.5^{\mathrm{b}} \pm 0.1$ & $4.5^{\mathrm{b}} \pm 0.1$ & $3.6^{c} \pm 0.1$ & $3.9^{c} \pm 0.1$ & 0.001 \\
\hline Neutral detergent fiber & $74.1^{\mathrm{b}} \pm 0.2$ & $77.4^{\mathrm{b}} \pm 0.2$ & $77.2^{\mathrm{ab}} \pm 0.1$ & $77.4^{\mathrm{ab}} \pm 0.4$ & $78.3^{\mathrm{a}} \pm 0.3$ & $78.8^{a} \pm 0.2$ & 0.001 \\
\hline Lignin & $4.1^{\mathrm{ab}} \pm 0.1$ & $4.0^{\mathrm{b}} \pm 0.1$ & $4.1^{\mathrm{ab}} \pm 0.1$ & $4.1^{\mathrm{ab}} \pm 0.1$ & $4.1^{\mathrm{ab}} \pm 0.4$ & $4.3^{\mathrm{a}} \pm 0.1$ & 0.003 \\
\hline IVOMD & $55.5^{\mathrm{a}} \pm 0.4$ & $50.2^{\mathrm{b}} \pm 0.7$ & $50.8^{\mathrm{b}} \pm 0.2$ & $48.7^{b} \pm 0.9$ & $49.4^{\mathrm{b}} \pm 0.1$ & $50.5^{\mathrm{b}} \pm 0.4$ & 0.001 \\
\hline
\end{tabular}

Averages followed by distinct letters in the line differ from one another by the Tukey test ( $<<0.05)$. IVOMD: in vitro organic matter digestibility.

Los promedios seguidos de letras distintas en la línea difieren entre sí en la prueba de Tukey (P <0,05). IVOMD: digestibilidad in vitro de la materia orgánica.

The chemical composition of the stem was determined to be similar to that of the leaf, with higher crude protein levels and in vitro organic matter digestibility observed during the months with a higher precipitation rate, while higher values of the fibrous fractions were present in the dry-water transition months. The highest canopy heights observed during the rainy season could help increase the plants' support structures. The appearance of tissues with a higher nutritive value (tissue renewal) at this time (24) increases the nutritive value of leaves and stems.

The average daily gain of the animals in the pastures under different doses of residual $\mathrm{N}$ varied very little $(\mathrm{P}=0.765)$, with an average of $0.490 \pm 0.02 \mathrm{~kg} \mathrm{day}^{-1}$. This result is like due to the similar nutritive value of the leaves and stems across the pastures. The average daily gain was lower than that found by Araújo (2017) in pastures of Mombaça grass fertilized with three doses of $\mathrm{N}\left(100,200\right.$ and $300 \mathrm{~kg} \mathrm{ha}^{-1}$ of $\left.\mathrm{N}\right)$ during the rainy season of 2014/2015 ( 0.540 vs. $\left.0.490 \mathrm{~kg} \mathrm{day}^{-1}\right)$. The highest individual performance recorded by Araújo (2017) was probably due to the higher crude protein levels in the leaves (10.9 vs. 9.3\%) and the higher rate of in vitro organic matter digestibility (62.1\% vs. 55.3\%), due or direct effect of $\mathrm{N}$ that alters the crude protein content and forage digestibility (11). 
The stocking density was highest for the pasture under the residual effect of $300 \mathrm{~kg} \mathrm{ha}^{-1}$ of $\mathrm{N}$ and lowest for the one under the effect of $100 \mathrm{~kg} \mathrm{ha}^{-1} \mathrm{of} \mathrm{N}$, with intermediate value for the pastures under a residual effect of $200 \mathrm{~kg} \mathrm{ha}^{-1}$ (table 6). The stocking density followed the same pattern of FAR variation (table 2, page 302): as the residual level of $\mathrm{N}$ increased (table 2, page 302), more animals were needed to maintain the post-grazing height targets (40-50 cm), which consequently increased the stocking density.

Averages followed by distinct letters in the line differ from one another by the Tukey test $(\mathrm{P}<0.05)$. *Animal unit $(1 \mathrm{AU}=450 \mathrm{~kg}$ of live weight). DWG: daily weight gain per hectare. Los promedios seguidos de letras distintas en la línea difieren entre sí en la prueba de Tukey $(\mathrm{P}<0,05)$ * Unidad animal $(1 \mathrm{AU}=450 \mathrm{~kg}$ de peso vivo). DWG: aumento de peso diario por hectárea.
Table 6. Performance of beef cattle (average \pm standard error) in Mombaça pastures under residual nitrogen effect.

Tabla 6. Producción del ganado de carne (media \pm error estándar) en pasturas de Mombaça bajo efecto de nitrógeno residual.

\begin{tabular}{|c|c|c|c|c|}
\hline \multirow{2}{*}{ Variables } & \multicolumn{3}{|c|}{ Doses of $\mathrm{N}\left(\mathrm{kg} \mathrm{ha}^{-1} \mathrm{de} \mathrm{N}\right)$} & \multirow{2}{*}{ P Value } \\
\hline & 100 & 200 & 300 & \\
\hline Stocking rate $\left(\mathrm{AU} \mathrm{ha}^{-1}\right)^{*}$ & $2.7^{\mathrm{b}} \pm 0.2$ & $3.1^{\mathrm{ab}} \pm 0.2$ & $4.0^{\mathrm{a}} \pm 0.1$ & 0.013 \\
\hline DWG (kg ha-1 of live weight) & $466.7^{b} \pm 28.3$ & $535.9^{\mathrm{ab}} \pm 31.6$ & $691.5^{\mathrm{a}} \pm 33.1$ & 0.011 \\
\hline
\end{tabular}

Brâncio et al. (2003b) report a stocking density of $2.0 \mathrm{AU} /$ ha and an individual weight gain of $0.500 \mathrm{~kg} \mathrm{day}^{-1}$ for Nellore cattle fed on Mombaça pasture fertilized with $50 \mathrm{~kg} \mathrm{ha}^{-1}$ of $\mathrm{N}$, with grazing management similar to that in the current research during the rainy season. Therefore, the residual effect of $100 \mathrm{~kg} \mathrm{ha}^{-1}$ of $\mathrm{N}$ impacts animal production in a way that is equivalent to the direct effect of $50 \mathrm{~kg} \mathrm{ha}^{-1}$ of $\mathrm{N}$; this repeats the results observed with regard to crop production.

The body weight per area gain was highest in the pastures under the residual effect of $300 \mathrm{~kg} \mathrm{ha}^{-1}$ of $\mathrm{N}$ and lowest in those at $100 \mathrm{~kg} \mathrm{ha}^{-1}$, with once again an intermediate value at $200 \mathrm{~kg} \mathrm{ha}^{-1}$ (table 6). This result can be attributed to the variation in stocking rate values, since pasture productivity is a result of the combination of individual performance and stocking rate $(13,19)$. Since there was no difference for individual performance between $\mathrm{N}$ doses, the observed behavior for stocking rate was repeated for the body weight gain per hectare.

Suspending $\mathrm{N}$ fertilization for one year after sequential fertilization over three years in Mombaça grass pastures can be adopted in strategic cases. As the producer cannot fertilize the entire area every year, this can help determine the fertilization scheduling of pastures. Furthermore, this strategy can help balance the high prices of fertilizer.

Finally, suspending $\mathrm{N}$ fertilization is a useful option when the objective of the production unit is not to obtain high gains from animals (such as in the case of producing breeding stock). In fact, this study revealed that the residual effect of $100 \mathrm{~N}$ is more or less equivalent to the direct effect of an annual application of $50 \mathrm{~kg} \mathrm{ha}^{-1}$ of $\mathrm{N}$. The residual dose of $100 \mathrm{~kg} \mathrm{ha}^{-1}$ of produced approximately 25\% less than the residual dose of $200 \mathrm{~kg} \mathrm{ha}^{-1}$ of and $50 \%$ less compared to the residual dose of $300 \mathrm{~kg} \mathrm{ha}^{-1}$ of $\mathrm{N}$.

\section{Conclusion}

Suspending the $\mathrm{N}$ fertilization of Mombaça grass for one year after three years of sequential fertilization with the same doses leaves a residual effect on the pasture structure and performance of beef cattle. However, this management is not advantageous. It reduces the rate of forage accumulation by an average of 50\%, causing a 55\% decrease in animal productivity. 


\section{REFERENCES}

1. Alvarenga, C. A. F.; Euclides, V. P. B.; Montagner, D. B.; Sbrissia, A. F.; Barbosa, R. A.; Araújo, A. R. 2020. Animal performance and sward characteristics of Mombaça guineagrass pastures subjected to two grazing frequencies. Tropical Grasslands-Forrajes Tropicales. 8(1): 1-10.

2. Araújo, I. M. M. 2017. Produção animal em pastos de capim-mombaça submetidos a doses de nitrogênio. Faculdade de Medicina Veterinária e Zootecnia, UFMS (latitude $20^{\circ} 27^{\prime} \mathrm{S}$ and longitude $54^{\circ} 37^{\prime}$ W). Tese de Doutorado em Ciência Animal. Universidade Federal de Mato Grosso do Sul. Campo Grande. Brasil. 66 p.

3. Barbosa, L. F. 2018. Acúmulo de forragem e desempenho animal em pastos de capim-mombaça sob doses de nitrogênio e pastejo intermitente. Universidade Federal da grande Dourados (latitude $20^{\circ} 27^{\prime} \mathrm{S}$ and longitude $54^{\circ} 37^{\prime} \mathrm{W}$ ). Tese de mestrado em Zootecnia. Universidade Federal da Grande Dourados. Dourados. Brasil. 57p.

4. Basso, K. C.; Cecato, U.; Lugão, S. M. B.; Gomes, J. A. N.; Barbero, L. M.; Mourão, G. B. 2010. Morfogênese e dinâmica do perfilhamento em pastos de Panicum maximum Jacq. cv. IPR-86 Milênio submetido a doses de nitrogênio. Revista Brasileira de Saúde e Produção Animal. 11(4): 976-989.

5. Bernardi, A.; Silva, A. W. L.; Baretta, D. 2018. Estudo metanalítico da resposta de gramíneas perenes de verão à adubação nitrogenada. Arquivos Brasileiro de Medicina Veterinária e Zootecnia. 70(2): 545-553.

6. Brâncio, P. A.; Nascimento Júnior, D.; Euclides, V. P. B.; Fonseca, D. M.; Almeida R. G.; Macedo, M. C. M.; Barbosa, R. A. 2003a. Avaliação de Três cultivares de Panicum maximum Jacq. Sob Pastejo: Disponibilidade de Forragem, Altura do Resíduo Pós-Pastejo e Participação de Folhas, Colmos e Material Morto. Revista Brasileira de Zootecnia. 32(1): 55-63.

7. Brâncio, P. A.; Euclides, V. P. B.; Nascimento Júnior, D.; Fonseca, D. M.; Almeida R. G.; Macedo, M. C. M.; Barbosa, R. A. 2003b. Avaliação de três cultivares de Panicum maximum Jacq. Sob pastejo: composição da dieta, consumo de matéria seca e ganho de peso animal. Revista Brasileira de Zootecnia. 32(5): 1037-1044.

8. Briske, D. D.; Derner, J. D.; Brown, J. R.; Fuhlendorf, S. D.; Teague, W. R.; Havstad, K. M. 2008. Rotational grazing on rangelands: Reconciliation of perception and experimental evidence. Rangeland Ecology \& Management. 61(1): 3-17.

9. Campos, F. P.; Nicácio, D. R. O.; Sarmento, P.; Cruz, M. C. P.; Santos, T. M.; Faria, A. F. G. 2016. Show more chemical composition and in vitro ruminal digestibility of hand-plucked samples of Xaraés palisade grass fertilized with incremental levels of nitrogen. Animal Feed Science and Technology. 215(3): 1-12.

10. Carnevalli, R. A.; Da Silva, S. C.; Bueno, A. A. O.; Uebele, M. C.; Bueno, F. O.; Hodgson, J. 2006. Herbage production and grazing losses in Panicum maximum cv. Mombaça under four grazing managements. Tropical Grasslands. 40(3): 65-176.

11. Castagnara, D. D.; Mesquita, E. E.; Neres, M. A.; Oliveira, P. S. R.; Deminicis, B. B.; Bamberg, R. 2011. Valor nutricional e características estruturais de gramíneas tropicais sob adubação nitrogenada. Archivos de Zootecnia. 60(232): 931-942.

12. Chapman, D. F.; Lemaire, G. 1993. Morphogenic and structural determinants of plant regrowth after defoliation. In: Proceedings of the 17 th International Grassland Congress. Edited by M. J. Baker (Ed.). New Zealand. 55-64.

13. Difante, G. S.; Euclides, V. P. B.; Nascimento Júnior, D.; Da Silva, S. C.; Barbosa, R. A.; Torres Junior, R. A. A. 2010. Desempenho e conversão alimentar de novilhos de corte em capim-tanzânia submetido a duas intensidades de pastejo sob lotação rotativa. Revista Brasileira de Zootecnia. 39(1): 33-41.

14. Difante, G. S.; Nascimento Júnior, D.; Da Silva, S. C.; Euclides, V. P. B.; Montagner, D. B.; Silveira, C. T. 2011. Características morfogênicas e estruturais do capim-marandu submetido a combinações de alturas e intervalos de corte. Revista Brasileira de Zootecnia. 40(5): 955-963.

15. Emerenciano Neto, J. V.; Difante, G. S.; Lana, Â. M. Q.; Medeiros, H. R.; Aguiar, E. M.; Montagner, D. B. 2018. Forage quality and performance of sheep in Massai grass pastures managed at pre-grazing canopy heights. South African Journal of Animal Science. 48(6): 1073-1081.

16. Euclides, V. P. B.; Macedo, M. C. M.; Zimmer, A. H.; Medeiros, R. N.; Oliveira, M. P. 2007. Características do pasto de capim-tanzânia adubado com nitrogênio no final do verão. Pesquisa Agropecuária Brasileira. 42(8): 1189-1198.

17. Euclides, V. P. B.; Lopes, F. C.; Nascimento Junior, D.; Da Silva, S.; Difante, G. S.; Barbosa, R. A. 2015. Steer performance on Panicum maximum (cv. Mombaça) pastures under two grazing intensities. Animal Production Science. 56(11): 1849-1856.

18. Euclides, V. B. P.; Carpejani, G. C.; Montagner, D. B.; Nascimento Junior, D.; Barbosa, R. A.; Difante, G. S. 2017. Maintaining post-grazing sward height of Panicum maximum (cv. Mombaça) at $50 \mathrm{~cm}$ led to higher animal performance compared with postgrazing height of $30 \mathrm{~cm}$. Grass and Forage Science. 73(1): 174-182.

19. Euclides, V. P. B.; Costa, F. P.; Euclides Filho, K.; Montagner, D. B.; Figueiredo, G. R. 2018. Biological and economic performance of animal genetic groups under different diets. Bioscience Journal. 34(6): 1683-1692. 
20. Faria, L. N.; Zanine, A. M.; Ferreira, D. J.; Ribeiro, M. D.; Souza, A. L.; Geron, L. J. V.; Ricardo Martins Araujo Pinho, R. M. A.; Santos, E.M. 2019. Effects of nitrogen fertilization and seasons on the morphogenetic and structural characteristics of Piatã (Brachiaria brizantha) grass. Revista de la Facultad de Ciencias Agrarias. Universidad Nacional de Cuyo. Mendoza. Argentina. 51(2): 42-54.

21. Instituto Nacional de Meteorologia (INMET). 2018. Climatologia: mapas. http://www.inmet.gov. br (accessed june 2018).

22. Liu, E.; Yan, C.; Mei, X.; He, W.; Bing, S. H.; Ding, L.; Liu, Q.; Liu, S.; Fan, T. 2010. Long-term effect of chemical fertilizer, straw, and manure on soil chemical and biological properties in northwest China. Geoderma. 158(1): 173-180.

23. Lopes, M. N.; Cândido, M. J. D.; Pompeu, R. C. F. F.; Silva, R. G.; Bezerra, F. M. L. 2011. After cut structural components of massai grass under five nitrogen fertilizer levels. Revista Ciência Agronômica. 42(2): 518-525.

24. Luna, A. A.; Difante, G. S.; Montagner, D. B.; Emerenciano Neto, J. V.; Araújo, I. M. M.; Oliveira, L. E. C. 2014. Características morfogênicas e acúmulo de forragem de gramíneas forrageiras, sob corte. Bioscience Journal. 30(6): 1803-1810.

25. Machado, L. A. Z.; Fabrício, A. C.; Gomes, A.; Assis, P. G. G.; Lempp, B.; Maraschin, G. E. 2008. Desempenho de animais alimentados com lâminas foliares, em pastagem de capim marandu. Pesquisa Agropecuária Brasileira. 43(11): 1609-1616.

26. Merten, G. C.; Shenk, J. S.; Barton, F. E. 1985. Near infrared reflectance spectroscopy (NIRS), analysis of forage quality. Washington: USDA. ARS. 110p. (Agriculture Handbook, 643).

27. Montagner, D. B.; Nascimento Júnior, D.; Sousa, B. M. L.; Vilela, H. H.; Silveira, M. C. T.; Euclides, V. P. B. 2012. Morphogenesis in guinea grass pastures under rotational grazing strategies. Revista Brasileira de Zootecnia. 41(4): 883-888.

28. Moreira, L. M.; Santos, M. E. R.; Fonseca, D. M.; Martuscello, J. A.; Morais, R. V.; Mistura, C. 2011. Produção animal em pastagem de capim-braquiária adubada com nitrogênio. Arquivo Brasileiro de Medicina Veterinária e Zootecnia. 63(40): 914-921.

29. Novakowiski, J. H.; Sandini, I. E.; Falbo, M. K.; Moraes, A.; Novakowiski, J. H.; Cheng, N. C. 2011. Residual effect of nitrogen fertilization and Azospirillum brasilense inoculation in the maize culture. Semina: Ciências Agrárias. 32(1): 1687-1698.

30. Paiva, J. P.; Da Silva, S. C.; Pereira, L. E. T.; Guarda, V. D. A.; Pereira, P. M.; Caminha, F. O. 2012. Structural characteristics of tiller age categories of continuously stocked Marandu palisade grass swards fertilized with nitrogen. Revista Brasileira de Zootecnia. 41(1): 24-29.

31. Petersen, R. G.; Lucas Junior, H. L. 1968. Computing methods for the evaluation of pastures by means of animal response. Agronomy Journal. 60(6): 682-687.

32. Santos, M. E. R.; Fonseca, D. M.; Balbino, E. M.; Monnerat, J. P. I. S.; Silva, S. P. 2009. Caracterização de perfilhos em pastos de capim-braquiária diferidos e adubados com nitrogênio. Revista Brasileira de Zootecnia. 38(4): 643-649.

33. Santos, M. E. R.; Fonseca, D. M.; Pimentel, R. M.; Silva, G. P.; Gomes, V. M.; Silva, S. P. 2011. Número e peso de perfilhos no pasto de capim-braquiária sob lotação contínua. Acta Scientiarum. Animal Sciences. 33(2): 131-136.

34. Sbrissia, A. F.; Euclides, V. P. B.; Barbosa, R. A.; Montagner, D. B.; Padilha, D. A.; Santos, G. T.; Zanini, G. D.; Duchini, P. G.; Da Silva, S. C. 2013. Grazing management flexibility in pastures subjected to rotational stocking management: herbage production and chemical composition of Kikuyu-grass sward. Proceedings International Grassland Congress. The Ecology of Grassland and Forage Ecosystems. 22(1): 1038-1040.

35. Świtek, S.; Takacs, V.; Sawinska, Z.; Kosiada, T.; Tryjanowskia, P. 2019. Mineral nitrogen fertilisers remain a crucial factor even in the ecological intensification of agriculture. Acta Agriculturae Scandinavica. Section B-Soil \& Plant Science. 69(4): 311-316.

36. Villaseñor, D.; Zagal, E.; Stolpe, N.; Hirzel, J. 2015. Relationship between mineralized nitrogen during anaerobic incubations and residual effect of nitrogen fertilization in two rice paddy soils in Chile. Chilean Journal of Agricultural Research. 75(1): 98-104.

37. Vitor, C. M. T.; Fonseca, D. M.; Moreira, L. M.; Fagundes, J. L.; Nascimento Junior, D.; Ribeiro Junior, J. I. 2008. Rendimento e composição química do capim-braquiária introduzido em pastagem degradada de capim-gordura. Revista Brasileira de Zootecnia. 37(12): 2107-2114.

\section{ACKNOWLEDGEMENTS}

The Coordination of Improvement of Higher Level Personnel - Brazil (CAPES) for the financial incentive - Financing Code 001. Support from the Federal University of Mato Grosso do Sul, CNPq, Embrapa Beef Cattle and the Federal University of Rio Grande do Norte. 